\title{
Oxidized-HDL $\mathrm{L}_{3}$ modulates the expression of Cox-2 in human endothelial cells
}

\author{
ELISA CALLEGARI $^{1 *}$, GIUSEPPE D. NORATA ${ }^{1,3^{*}}$, HIROYASU INOUE $^{2}$ and ALBERICO L. CATAPANO ${ }^{1,3}$ \\ ${ }^{1}$ Department of Pharmacological Sciences, University of Milan, Milan, Italy; \\ ${ }^{2}$ Department of Food and Science and Nutrition, Nara Women's University, Nara, Japan; \\ ${ }^{3}$ Center of the Italian Society for the Study of Atherosclerosis, Bassini Hospital, Cinisello Balsamo, Italy
}

Received January 9, 2006; Accepted March 13, 2006

\begin{abstract}
Modified high density lipoprotein (HDL) has been suggested to modulate endothelial expression of proinflammatory genes. Since oxidised HDL (Ox-HDL) has been found in atheromatous plaques and receptors for modified HDL are present on endothelial cells, we investigated the effect of $\mathrm{Ox}-\mathrm{HDL}_{3}$ on the expression of Cox-1 or Cox-2. Ox-HDL ${ }_{3}$, increased Cox-2 mRNA and protein expression in endothelial cells while no effect on Cox-1 expression was observed. The intracellular pathways involved in this effect were investigated. The incubation with specific inhibitors of intracellular kinases showed that $\mathrm{PI} 3 \mathrm{~K}$ is mainly involved in the $\mathrm{Ox}-\mathrm{HDL}_{3}$-dependent Cox-2 induction. Transient transfection experiments suggested that the NF-IL6 response element in the proximal promoter (-327 to 59) is involved in $\mathrm{Ox}_{-} \mathrm{HDL}_{3}$-mediated Cox-2 expression. These data suggest that Ox-HDL induce Cox-2 expression in endothelial cells through a PI3K/NF-IL6-dependent pathway.
\end{abstract}

\section{Introduction}

Numerous clinical and epidemiological studies have demonstrated the inverse relationship between HDL cholesterol and the risk of atherosclerosis (1). Beyond the ability of HDL to remove cholesterol from peripheral tissue, HDL particles have additional beneficial effects on the vascular wall (1-3). HDL can inhibit the chemotaxis of monocytes, the adhesion of leukocytes to the endothelium, the LDL oxidation, the endothelial dysfunction and apoptosis. HDL can also act on the vascular tone through the release of vasorelaxant molecule like NO and prostacyclin (PGI2) (3). We have demonstrated

Correspondence to: Dr Giuseppe D. Norata, Department of Pharmacological Sciences, University of Milan, Via Balzaretti 9, I-20133 Milan, Italy

E-mail: danilo.norata@unimi.it

${ }^{*}$ Contributed equally

Key words: high density lipoprotein, Cox-2, endothelial cells previously that HDL increases the release of PGI2 through the induction of cyclooxygenase 2 (Cox-2) and the coupling with PGI syntase in endothelial cells (4). It has been shown that modification of HDL could affect their function $(5,6)$. Oxidised (Ox-) and modified HDL are present in atherosclerotic plaques (7-9) and human analogues of SR-B1 and LOX-1 have been identified as receptors for modified HDL on endothelial cells. In vitro, HDL is readily modified using a variety of oxidants (10), with kinetics similar to that reported for LDL (11). Ox-HDL loses its ability to promote cholesterol efflux (5), to induce nitric oxide release (12) and to modulate the expression of matrix-degrading protease and PAI-1 in endothelial cells $(13,14)$.

In the present study, we have investigated the effect of $\mathrm{Ox}_{-} \mathrm{HDL}_{3}$ on the expression of Cox-2 in endothelial cells and the molecular mechanisms involved.

\section{Materials and methods}

Materials. HDL subfraction 3 (d 1.125-1.21 g/ml) was obtained from freshly isolated human plasma by preparative ultracentrifugation and dialyzed in PBS containing 0.01\% EDTA (15). $\mathrm{HDL}_{3}$ (1 mg protein/ml) was oxidized with $20 \mu \mathrm{M}$ $\mathrm{Cu}_{2} \mathrm{SO}_{4}$ for $24 \mathrm{~h}$ at $37^{\circ} \mathrm{C}$, as described (13). The oxidation was blocked by the addition of $40 \mu \mathrm{M}$ butylated hydroxytoluene (BHT). Under these conditions, we have previously shown that lipoprotein oxidation does not proceed further at $4^{\circ} \mathrm{C}$. The LPS content of $\mathrm{HDL}_{3}$ was measured using an endotoxin kit from Sigma. No contamination was detected (data not shown). Native $\mathrm{HDL}_{3}$ and $\mathrm{Ox}-\mathrm{HDL}_{3}$ were used within $6 \mathrm{~h}$ of preparation.

The MEK inhibitor, U0126 (New England Biolabs, Germany), the p38 MAPK inhibitor SB 203580 (Sigma, Italy), and the PI3K inhibitor Ly 294002 (Alexis, Italy) were used at a final concentration of $10 \mu \mathrm{mol} / 1,0.5 \mu \mathrm{mol} / 1$ and $50 \mu \mathrm{mol} / 1$, respectively (15). At these concentrations the inhibitors effectively decreased the phosphorylation of the downstream targets (data not shown).

HUVECs were isolated as described (16) and cultured under standard conditions in medium M-199 containing 20\% FCS (fetal calf serum), heparin $(15 \mathrm{U} / \mathrm{ml})$ and ECGF (endothelial cell growth factor, $20 \mu \mathrm{g} / \mathrm{ml}$ ) (Roche, Italy). The cells 


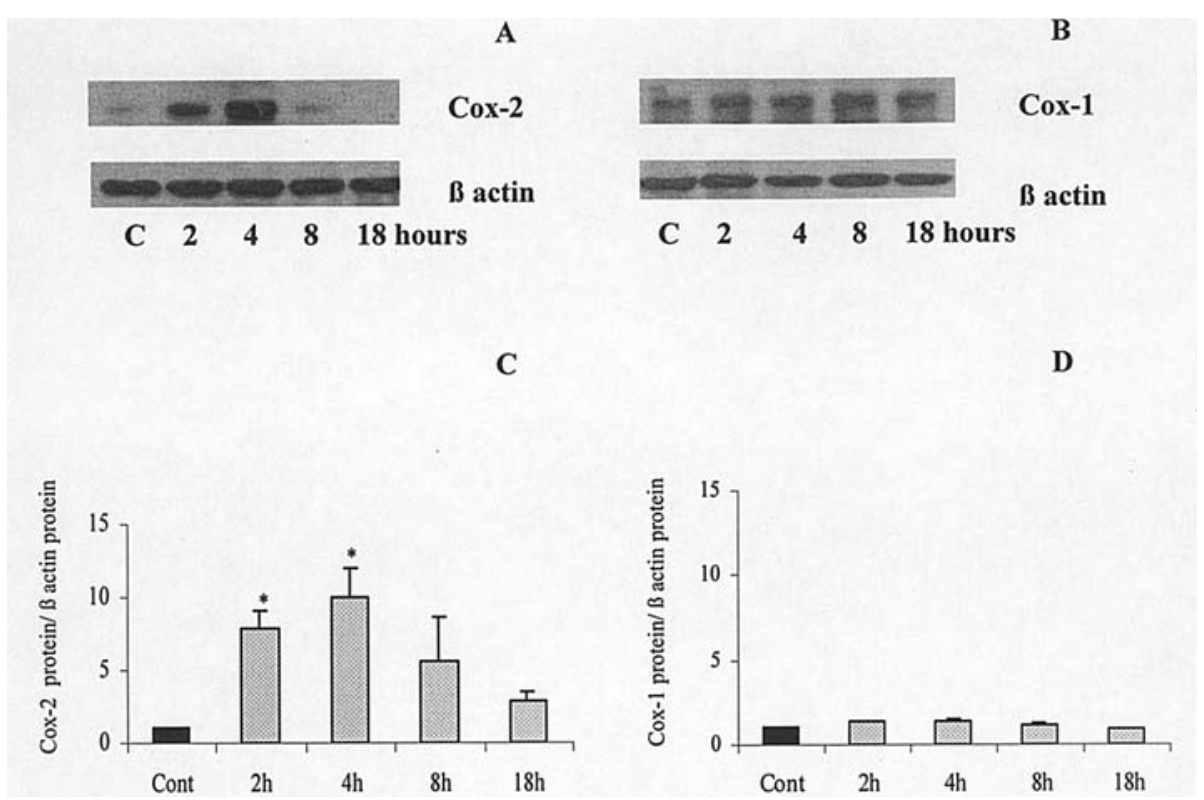

Figure 1. Effect of Ox-HDL 3 on Cox-2 and Cox-1 protein expression in endothelial cells. HUVECs were incubated with Ox-HDL $30 \mu \mathrm{g} / \mathrm{ml}$ for $2,4,8,18 \mathrm{~h}$. Cells were lysed and the lysates were analysed by immunoblotting using anti Cox-2 (A) and anti Cox-1 (B). The blot was stripped and reprobed with anti $B$-actin to confirm equal expression (A and B). Results from 3 different experiments are presented in (C) and (D) (mean \pm SD; ${ }^{*} \mathrm{p}<0.05$ vs control cells).

were used within the 4 th passage. Cells were plated in 6-well plates and used after $48 \mathrm{~h}$ as subconfluent cultures. In all experiments, cells were preincubated with serum-free medium for $6 \mathrm{~h}$, and then native or $\mathrm{Ox}-\mathrm{HDL}_{3}$ were added for different times. Cells were incubated in the presence or absence of compounds with appropriate chemicals or vehicle additions (DMSO, $0.1 \% \mathrm{vol} / \mathrm{vol}$ ).

Real-time quantitative RT-PCR. Total RNA was extracted and underwent reverse transcription as described $(4,17)$. Three $\mu 1$ of cDNA was amplified by real-time quantitative PCR with 1X SYBER Green universal PCR mastermix (Bio$\mathrm{Rad}$ ) (4). The specificity of the SYBER Green fluorescence was tested by plotting fluorescence as a function of temperature to generate a melting curve of the amplicon. The melting peaks of the amplicons were as expected (data not shown). The primers used, the amplicon size and the melting temperature have been described previously (4). Each sample was analyzed in duplicate using the $\mathrm{IQ}^{\mathrm{TM}}$-Cycler (Bio-Rad). The PCR amplification was related to a standard curve ranging from $10^{-11} \mathrm{M}$ to $10^{-14} \mathrm{M}$.

Immunoblotting. Cox-1 and Cox-2 expression was investigated as described (18). Briefly, cells were plated in 6-well plates and treated with $\mathrm{Ox}-\mathrm{HDL}_{3}$ or native $\mathrm{HDL}_{3}$ for 5-40 min, then lysed using a Tris-glycine buffer (0.25 M Tris, $0.173 \mathrm{M}$ glycine) containing 3\% SDS and $1 \mathrm{mM}$ PMSF (phenylmethylsulfonil fluoride). Aliquots of the samples $(15 \mu \mathrm{g})$ were diluted in a $2 \% ß$-mercaptoethanol buffer containing glycerol and bromophenol blue and electrophoresed on a $12 \%$ SDS-PAGE, then transferred onto a nitrocellulose membrane using a Trans Blot Cell (Hoefer Scientific Instrument, San Francisco, CA) (19). The membrane was saturated at room temperature in PBS containing 3\% BSA for $1 \mathrm{~h}$, washed with PBS-T (PBS containing $0.1 \%$ Tween-20), then incubated overnight at $4^{\circ} \mathrm{C}$ with a mixture of primary antibody (1:1000 incubation at room temperature for $1 \mathrm{~h}$ for Cox-1 and Cox-2 antibodies;
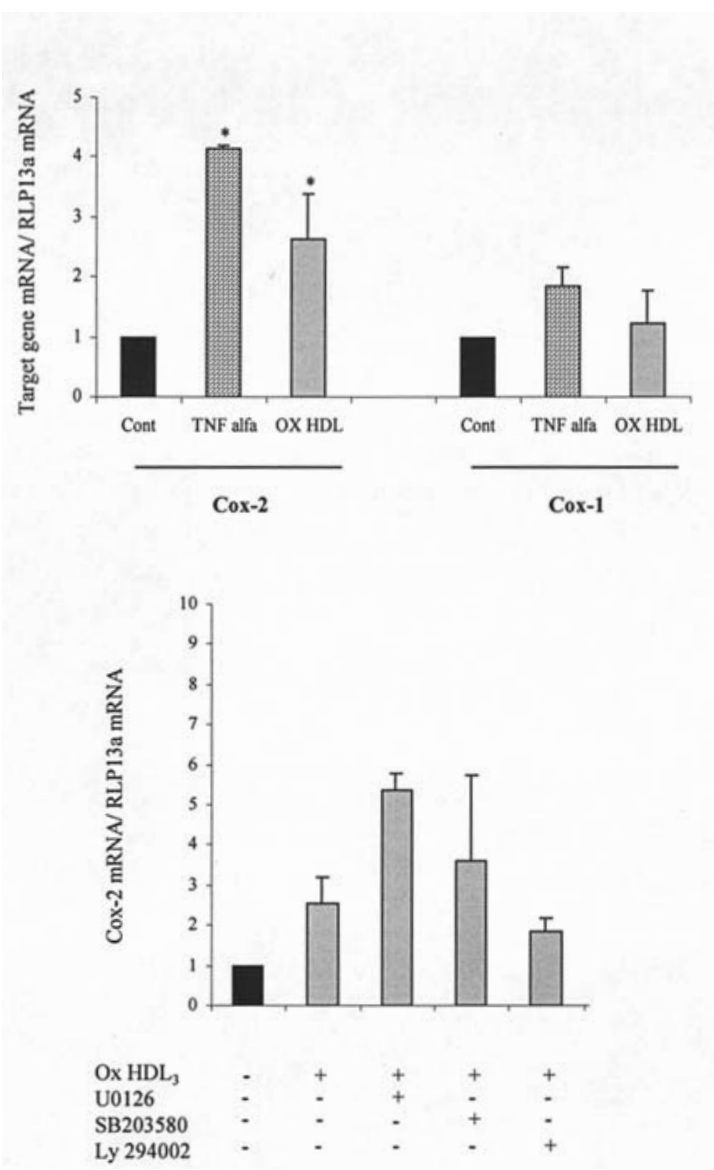

B

Figure 2. Effects of kinase inhibitors on $\mathrm{Ox}-\mathrm{HDL}_{3}$ induced Cox-2 mRNA expression in endothelial cells. (A) HUVECs were incubated for $2 \mathrm{~h}$ for mRNA detection with $\mathrm{Ox}-\mathrm{HDL}_{3}(30 \mu \mathrm{g} / \mathrm{ml})$, or TNF- $\alpha(10 \mathrm{ng} / \mathrm{ml})$ used as positive control. Cox-2 and Cox-1 mRNA expression was measured by quantitative real-time PCR and normalised to RLP13a mRNA expression. (B) HUVECs were incubated for $2 \mathrm{~h}$ with $\mathrm{Ox}-\mathrm{HDL}_{3}(30 \mu \mathrm{g} / \mathrm{ml})$ alone or in presence of U0126 $(10 \mu \mathrm{M})$ or SB $203580(0.5 \mu \mathrm{M})$, Ly $294002(50 \mu \mathrm{M})$. Cox-2 mRNA expression was measured by quantitative real-time PCR and normalised to RLP13a mRNA expression. The mean \pm SD from 3 different experiments is shown. ${ }^{*} \mathrm{p}<0.05$ vs control cells. 
A

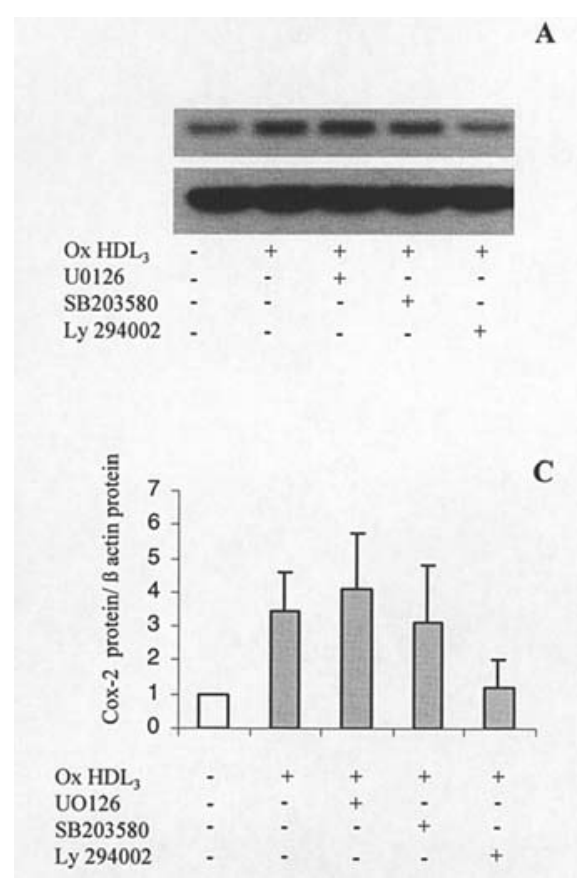

(20)

B

Cox-2

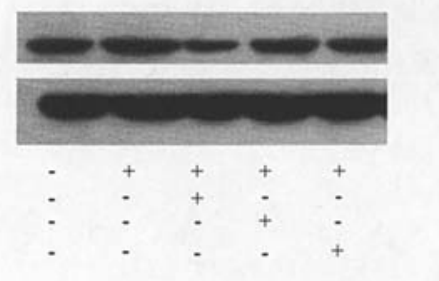

Cox-1

B actin

$\mathrm{Ox} \mathrm{HDL}_{3}$

U0126

SB203580

Ly 294002

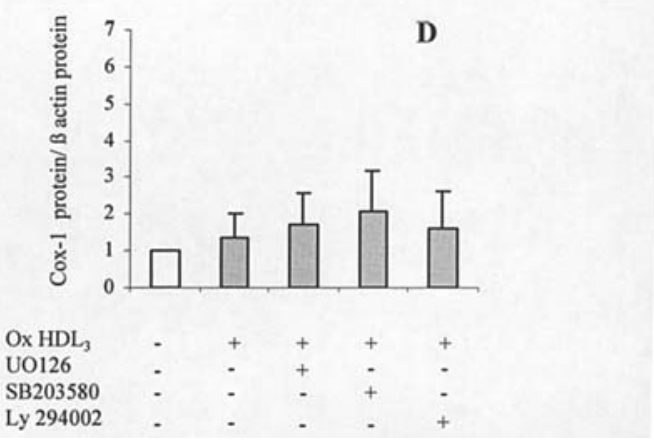

Figure 3. Effects of kinase inhibitors on Ox-HDL 3 induced Cox-2 and Cox-1 protein expression in endothelial cells. HUVECs were incubated for $6 \mathrm{~h}$ with Ox$\mathrm{HDL}_{3}(30 \mu \mathrm{g} / \mathrm{ml})$ alone or in presence of $\mathrm{U} 0126(10 \mu \mathrm{M})$ or SB $203580(0.5 \mu \mathrm{M})$, Ly $294002(50 \mu \mathrm{M})$ and SH-5 $(10 \mu \mathrm{M})$. Cells were lysed and the lysates were analysed by immunoblotting using anti Cox-2 (A) and anti Cox-1 (B). The blot was stripped and reprobed with anti $B$-actin to confirm equal expression (A and B). Results from 3 different experiments are presented in (C) and (D) (mean \pm SD)

1:1000 incubation at room temperature for $1 \mathrm{~h}$ for $\beta$-actin antibody) followed by a 1:1000 dilution of peroxidaseconjugated anti-mouse IgG (Sigma) or peroxidase-conjugated anti rabbit IgG (Bio-Rad, Italy). Immunocomplexes were detected by an enhanced chemiluminescence method (ECL, Amersham, Italy), followed by autoradiography and quantified by the Image program (NIH 1.52).

Transfection assay. Transient transfection experiments were first performed using HUVECs and EAhy 926 cells; however, the efficiencies reached were very low with a high degree of cytotoxicity (data not shown). As human Cox-2 promoter regulation is similar in a wide number of cell types we performed transfection experiments in $\mathrm{CHO}$ cells, a cell line widely used for studies involving the effects of HDL in vitro $(4,20)$. CHO cells were transiently transfected with Cox-2 (nucleotide $-327 /+59)$, the NF-кB mutated site (KBM) or the NF-IL6 mutated site (ILM) luciferase reporter vectors using a calcium phosphate precipitation method as described (4). B-galactosidase activity was assayed as described (14). Luciferase activity was determined and normalized to the $\beta$-gal activity of the cotransfected $\mathrm{pSV}$ - $\beta$-galactosidase construct.

Statistical analysis. Data presented in the text and figures are mean \pm SD and are representative of 4 different experiments. Statistical analysis was performed by ANOVA with the use of Statsoft Statistica Package.

\section{Results}

The experimental set-up was designed to analyse endothelial cell expression of Cox-1 and Cox-2 in the presence of Ox$\mathrm{HDL}_{3}$ in relation to basal conditions. The cells were kept in a serum-free medium for $6 \mathrm{~h}$; then $\mathrm{HDL}_{3}(30 \mu \mathrm{g} / \mathrm{ml})$ or Ox-HDL $(30 \mu \mathrm{g} / \mathrm{ml})$ were added for $4 \mathrm{~h}$. Control cells were incubated for $4 \mathrm{~h}$ with the experimental medium containing the same percentage of PBS that was added with the stimulus.

Cox- 2 protein was expressed at low levels in unstimulated cells and was strongly induced $2 \mathrm{~h}$ after exposure to $\mathrm{Ox}-\mathrm{HDL}_{3}$ $(30 \mu \mathrm{g} / \mathrm{ml})$; the induction was maximal after $4 \mathrm{~h}$ and decreased after $8 \mathrm{~h}$ (Fig. 1). Cox-2 expression in unstimulated cells remained low at all time points (data not shown). Ox-HDL did not affected Cox-1 protein expression (Fig. 1). Next we examined the effects of $\mathrm{Ox}-\mathrm{HDL}_{3}$ on the Cox-1 and Cox-2 mRNA expression. The cells were kept in a serum-free medium for $6 \mathrm{~h}$; then $\mathrm{Ox}_{-} \mathrm{HDL}_{3}(30 \mu \mathrm{g} / \mathrm{ml})$ or TNF- $\alpha(10 \mathrm{ng} / \mathrm{ml})$, used as positive control, were added for $2 \mathrm{~h}$. We observed the induction of Cox-2 mRNA expression by $\mathrm{Ox}-\mathrm{HDL}_{3}(30 \mu \mathrm{g} / \mathrm{ml})$ or TNF- $\alpha(10 \mathrm{ng} / \mathrm{ml})$, while no effect was observed on Cox-1 mRNA expression.

To investigate the role of ERK1/2, p38 MAPK and $\mathrm{PI} 3 \mathrm{~K} / \mathrm{Akt}$ pathways in Cox-2 expression induced by Ox$\mathrm{HDL}_{3}$, cells were preincubated with the MEK1 inhibitor U0126, the p38 MAPK inhibitor SB 203580 and the PI3K inhibitor Ly 294002 for $1 \mathrm{~h}$; Ox-HDL $3(30 \mu \mathrm{g} / \mathrm{ml})$ were then added for 2 and $4 \mathrm{~h}$ to evaluate Cox-2 mRNA and protein expression (Figs. 2 and 3). U0126 was unable to block Ox-HDL-induced Cox-2 expression. SB 203580 partially inhibited Ox-HDL-induced Cox-2 expression while Ly 294002 completely abolished Ox-HDL-induced Cox-2 mRNA expression and partially inhibited protein expression. No effect of SB 203580 and Ly 294002 was observed on Cox-1 protein expression.

Next we examined the effects of Ox-HDL on the Cox-2 promoter activity. The human Cox-2 promoter region ( $-327 /$ +59) contains the NF- $\mathrm{B}$, the NF-IL6 and the CRE sites 


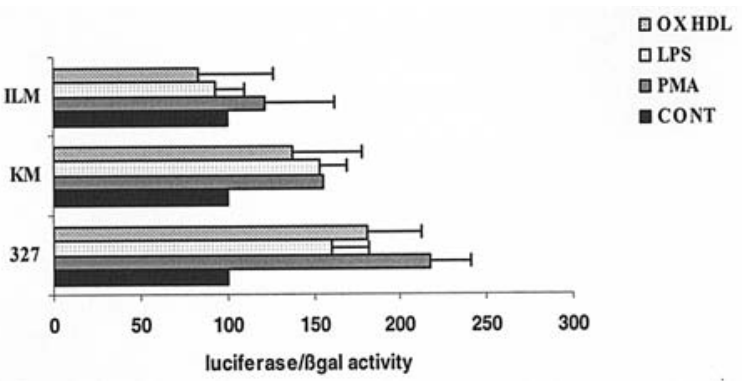

Figure 4. Identification of the regions responsible for $\mathrm{Ox}-\mathrm{HDL}_{3}$-induced promoter activity of the human Cox-2 gene. Following transfection, $\mathrm{CHO}$ cells were incubated for $6 \mathrm{~h}$ with LPS $(1 \mu \mathrm{g} / \mathrm{ml})$ or PMA $(50 \mathrm{ng} / \mathrm{ml})$ both used as positive control, and with $\mathrm{Ox}_{-} \mathrm{HDL}_{3}(30 \mu \mathrm{g} / \mathrm{ml})$. The results are presented as relative luciferase activity normalized to $\beta$-galactosidase activity. Each experiment was carried out in triplicate.

$(4,18)$. Transient transfection assay showed that Ox-HDL induced promoter activity by $199 \pm 27 \%$ (Fig. 4). PMA, used as positive control, induced promoter activity by $218 \pm 35 \%$ while LPS induced promoter activity by $160 \pm 29 \%$ (Fig. 4). Upon incubation with Ox-HDL, the promoter activity of the construct carrying the mutation at the NF- $\mathrm{B}$ site was $140 \pm 48 \%$, that of the construct carrying the mutation at the NF-IL6 site was $71 \pm 26 \%$ (Fig. 4). Upon incubation with PMA the promoter activity of the construct carrying the mutation at the NF- $\mathrm{KB}$ site was $155 \pm 14 \%$, that of the construct carrying the mutation at the NF-IL6 site was $93 \pm 13 \%$ (Fig. 4); finally upon incubation with LPS the promoter activity of the construct carrying the mutation at the NF- $\mathrm{KB}$ site was $156 \pm 24 \%$, that of the construct carrying the mutation at the NF-IL6 site was $83 \pm 32 \%$ (Fig. 4), thus suggesting a major role of the NF-IL6 site on the effect observed.

\section{Discussion}

Several lines of evidence have accumulated indicating that oxidative modification of HDL can occur in vivo $(10,11,21,22)$. Furthermore, investigations using the Ox-HDL-specific 9F5-3a antibody have indicated the presence of Ox-HDL in the intima of atheromatous plaques in the human abdominal aorta located specifically in aortic endothelial cells (7), and in sera from patients with chronic renal failure (23). In addition, oxidative modification of HDL not only attenuates its beneficial properties, such as stimulation of cholesterol efflux from foam cells (21), endothelium-dependent vasoreactivity (24) and anti-oxidative activity (10), but also generates a pro-atherogenic species that inhibits nitric oxide synthesis in endothelial cells (25) and induces production of reactive oxygen species and apoptosis via NF- $\mathrm{\kappa B}$ activation (26). Several genes involved in the inflammatory response observed during atherogenesis are modulated through the activation of the NF-кB pathway, including Cox-2 (27).

Here we demonstrated that Ox-HDL could play an harmful role by inducing Cox-2 expression. This effect was specific for Cox-2 as no effect on Cox-1 induction was observed and is dependent upon the activation of intracellular signalling pathways regulating the transcription machinery. We have previously shown that Ox-HDL could modulate PAI-1 expression through the activation of the p38 MAPK pathway promoting RNA stabilization (14). For Ox-HDL- induced Cox-2 expression the p38 MAPK or the ERK1/2 pathway seems to play a minor role, while the activation of the PI3K pathway is fundamental for Ox-HDL-dependent Cox-2 expression in agreement with previous observation with a different experimental setting (28).

To determine the specific transcription factor that is involved in the Ox-HDL mediated Cox-2 expression, we examined the effects of Ox-HDL on the luciferase activity of plasmids containing the Cox-2 promoter defective in the NF- $\mathrm{BB}$ or the NF-IL6 binding site $(4,18)$.

Our data clearly demonstrated that the NF-IL6 site is implicated is the response observed. NF-IL6 is a member of the $\mathrm{C} / \mathrm{EBP}$ family of transcription factors and is involved in inducing several acute-phase protein genes in response to immune and inflammatory stimulation. NF-IL6 also plays a mayor role in inducing the expression of Cox-2 by cytokines and endotoxin (29) thus suggesting that Cox-2 induction by Ox-HDL via NF-IL6 could depend on a pro-inflammatory activated endothelium.

What are the physiological implication(s) of our data? The possibility that Cox-2 plays a harmful role by catalysing the biosynthesis of pro-inflammatory prostanoids has been suggested. Cox-2 immunostaining has been observed in macrophages/foam cells, intimal and medial smooth muscle cells and endothelial cells in atherosclerotic arteries, whereas normal arteries contained no Cox-2 protein (27). Similarly, Schonbeck et al (30) found expression of both Cox-1 and Cox-2 by endothelial cells, smooth muscle cells and macrophages in atherosclerotic arteries, while normal arteries only expressed Cox-1. Furthermore, Cox-2 and prostaglandin synthase E colocalize in symptomatic lesions and are possibly involved in metalloprotease activation via $\mathrm{PGE}_{2}$ production (31) suggesting a role for $\mathrm{PGE}_{2}$ in plaques instability.

On the other hand, Cox-2 might play an atheroprotective role (27). In vitro laminar shear stress upregulates Cox-2 mRNA and protein in HUVEC, turbulent shear stress does not have this effect (32). Prostacyclin is a potent vasodilator, inhibits platelet aggregation and blocks leukocyte adhesion and activation (33). It is therefore possible that Cox-2 induced in endothelial cells at lesion-protected areas catalyses the formation of the anti-atherogenic molecule prostacyclin. These finding suggest the possibility that Cox-2 induction alone is not enough to drive prostaglandin production toward a pro-atherogenic or anti-atherogenic profile, but the prostanoids produced account for this effect. Future studies are thus warranted to identify the prostanoid profile induced by Ox-HDL in the endothelium.

In summary, we have shown that Ox-HDL induces Cox-2 expression in human endothelial cells through a PI3K, NFIL6-dependent pathway, suggesting a new mechanism by which Ox-HDL could modulate the inflammatory response in the arterial wall.

\section{Acknowledgements}

This work was supported by grants from FIRB (2001RBNE01HLAK_006), COFIN 2004 (2004065985_006 and 2004069574_003), CIRC (Consorzio Interuniversitario Ricerca Cardiovascolare) and SISA Lombardia (Società Italiana Studio Aterosclerosi). 


\section{References}

1. Norata GD and Catapano AL: Molecular mechanisms responsible for the anti-inflammatory and protective effect of HDL on the endothelium. Vasc Health Risk Manag 1: 119-129, 2005.

2. Nofer JR, Kehrel B, Fobker M, Levkau B, Assmann G and von Eckardstein A: HDL and arteriosclerosis: beyond reverse cholesterol transport. Atherosclerosis 161: 1-16, 2002.

3. Calabresi L, Gomaraschi M and Franceschini G: Endothelial protection by high-density lipoproteins: from bench to bedside. Arterioscler Thromb Vasc Biol 23: 1724-1731, 2003.

4. Norata GD, Callegari E, Inoue $H$ and Catapano AL: HDL3 induces cyclooxygenase- 2 expression and prostacyclin release in human endothelial cells via a p38 MAPK/CRE-dependent pathway: effects on COX-2/PGI-synthase coupling. Arterioscler Thromb Vasc Biol 24: 871-877, 2004.

5. Ferretti G, Bacchetti T, Negre-Salvayre A, Salvayre R, Dousset N and Curatola G: Structural modifications of HDL and functional consequences. Atherosclerosis 184: 1-7, 2006.

6. Norata GD, Pirillo A and Catapano AL: Modified HDL: biological and physiopathological consequences. Nutr Metab Cardiovasc Dis 2006.

7. Nakajima T, Origuchi N, Matsunaga T, Kawai S, Hokari S, Nakamura H, Inoue I, Katayama S, Nagata A and Komoda T: Localization of oxidized HDL in atheromatous plaques and oxidized HDL binding sites on human aortic endothelial cells. Ann Clin Biochem 37: 179-186, 2000.

8. Bergt C, Pennathur S, Fu X, Byun J, O'Brien K, McDonald TO, Singh P, Anantharamaiah GM, Chait A, Brunzell J, Geary RL, Oram JF and Heinecke JW: The myeloperoxidase product hypochlorous acid oxidizes HDL in the human artery wall and impairs ABCA1-dependent cholesterol transport. Proc Natl Acad Sci USA 101: 13032-13037, 2004.

9. Zheng L, Nukuna B, Brennan ML, Sun M, Goormastic M, Settle M, Schmitt D, Fu X, Thomson L, Fox PL, Ischiropoulos H, Smith JD, Kinter M and Hazen SL: Apolipoprotein A-I is a selective target for myeloperoxidase-catalyzed oxidation and functional impairment in subjects with cardiovascular disease. J Clin Invest 114: 529-541, 2004

10. Francis GA: High density lipoprotein oxidation: in vitro susceptibility and potential in vivo consequences. Biochim Biophys Acta 1483: 217-235, 2000

11. Thomas MJ, Chen Q, Zabalawi M, Anderson R, Wilson M, Weinberg R, Sorci-Thomas MG and Rudel LL: Is the oxidation of high-density lipoprotein lipids different than the oxidation of low-density lipoprotein lipids? Biochemistry 40: 1719-1724, 2001.

12. Marsche G, Heller R, Fauler G, Kovacevic A, Nuszkowski A, Graier W, Sattler W and Malle E: 2-Chlorohexadecanal derived from hypochlorite-modified high-density lipoprotein-associated plasmalogen is a natural inhibitor of endothelial nitric oxide biosynthesis. Arterioscler Thromb Vasc Biol 24: 2302-2306, 2004.

13. Norata GD, Pellegatta F, Hamsten A, Catapano AL and Eriksson P: Effects of HDL3 on the expression of matrixdegrading proteases in human endothelial cells. Int $\mathrm{J} \mathrm{Mol}$ Med 12: 73-78, 2003.

14. Norata GD, Banfi C, Pirillo A, Tremoli E, Hamsten A, Catapano AL and Eriksson P: Oxidised-HDL3 induces the expression of PAI- 1 in human endothelial cells. Role of p38MAPK activation and mRNA stabilization. Br J Haematol 127: 97-104, 2004.

15. Norata GD, Callegari E, Marchesi M, Chiesa G, Eriksson P and Catapano AL: High-density lipoproteins induce transforming growth factor-beta 2 expression in endothelial cells. Circulation 111: 2805-2811, 2005.

16. Norata GD, Pirillo A, Callegari E, Hamsten A, Catapano AL and Eriksson P: Gene expression and intracellular pathways involved in endothelial dysfunction induced by VLDL and oxidised VLDL. Cardiovasc Res 59: 169-180, 2003.
17. Norata GD, Bjork H, Hamsten A, Catapano AL and Eriksson P High-density lipoprotein subfraction 3 decreases ADAMTS-1 expression induced by lipopolysaccharide and tumor necrosis factor-alpha in human endothelial cells. Matrix Biol 22: 557-560, 2004.

18. Norata GD, Pirillo A, Pellegatta F, Inoue H and Catapano AL: Native LDL and oxidized LDL modulate cyclooxygenase-2 expression in HUVECs through a p38-MAPK, NF-kappaB, CRE dependent pathway and affect PGE2 synthesis. Int J Mol Med 14: 353-359, 2004.

19. Pirillo A, Norata GD, Zanelli T and Catapano AL: Overexpression of inducible heat shock protein 70 in Cos- 1 cells fails to protect from cytotoxicity of oxidized ldls. Arterioscler Thromb Vasc Biol 21: 348-354, 2001.

20. Baez JM, Barbour SE and Cohen DE: Phosphatidylcholine transfer protein promotes apolipoprotein A-I-mediated lipid efflux in Chinese hamster ovary cells. J Biol Chem 277: 6198-6206, 2002.

21. Nagano Y, Arai H and Kita T: High density lipoprotein loses its effect to stimulate efflux of cholesterol from foam cells after oxidative modification. Proc Natl Acad Sci USA 88: 6457-6461, 1991.

22. Salmon S, Santus R, Maziere JC, Aubailly M and Haigle J: Modified apolipoprotein pattern after irradiation of human highdensity lipoproteins by ultraviolet B. Biochim Biophys Acta 1128: 167-173, 1992.

23. Tsumura M, Kinouchi T, Ono S, Nakajima T and Komoda T: Serum lipid metabolism abnormalities and change in lipoprotein contents in patients with advanced-stage renal disease. Clin Chim Acta 314: 27-37, 2001

24. Chin JH, Azhar S and Hoffman BB: Inactivation of endothelial derived relaxing factor by oxidized lipoproteins. J Clin Invest 89: 10-18, 1992.

25. Nuszkowski A, Grabner R, Marsche G, Unbehaun A, Malle E and Heller R: Hypochlorite-modified low density lipoprotein inhibits nitric oxide synthesis in endothelial cells via an intracellular dislocalization of endothelial nitric-oxide synthase. J Biol Chem 276: 14212-14221, 2001

26. Matsunaga T, Hokari S, Koyama I, Harada T and Komoda T: NF-kappa B activation in endothelial cells treated with oxidized high-density lipoprotein. Biochem Biophys Res Commun 303: 313-319, 2003.

27. Linton MF and Fazio S: Cyclooxygenase-2 and inflammation in atherosclerosis. Curr Opin Pharmacol 4: 116-123, 2004.

28. Sheu ML, Chao KF, Sung YJ, Lin WW, Lin-Shiau SY and Liu SH: Activation of phosphoinositide 3-kinase in response to inflammation and nitric oxide leads to the up-regulation of cyclooxygenase- 2 expression and subsequent cell proliferation in mesangial cells. Cell Signal 17: 975-984, 2005.

29. Yamamoto K, Arakawa T, Ueda N and Yamamoto S: Transcriptional roles of nuclear factor kappa B and nuclear factorinterleukin- 6 in the tumor necrosis factor alpha-dependent induction of cyclooxygenase-2 in MC3T3-E1 cells. J Biol Chem 270: 31315-31320, 1995 .

30. Schonbeck U, Sukhova GK, Graber P, Coulter S and Libby P Augmented expression of cyclooxygenase-2 in human atherosclerotic lesions. Am J Pathol 155: 1281-1291, 1999.

31. Cipollone F, Prontera C, Pini B, Marini M, Fazia M, DeCesare D, Iezzi A, Ucchino S, Boccoli G, Saba V, Chiarelli F, Cuccurullo F and Mezzetti A: Overexpression of functionally coupled cyclooxygenase- 2 and prostaglandin $\mathrm{E}$ synthase in symptomatic atherosclerotic plaques as a basis of prostaglandin E(2)dependent plaque instability. Circulation 104: 921-927, 2001.

32. Topper JN, Cai J, Falb D and Gimbrone MA Jr: Identification of vascular endothelial genes differentially responsive to fluid mechanical stimuli: cyclooxygenase-2, manganese superoxide dismutase, and endothelial cell nitric oxide synthase are selectively up-regulated by steady laminar shear stress. Proc Natl Acad Sci USA 93: 10417-10422, 1996.

33. Vane JR and Botting RM: Pharmacodynamic profile of prostacyclin. Am J Cardiol 75: 3A-10A, 1995. 